\title{
骨移植を併用した人工膝関節置換術
}

\author{
福岡大学整形外科 \\ 毛利 正玄・緒方公介 \\ 原道也
}

\section{Bone Graft for Tibial Defects in Total Knee Arthroplasty}

\author{
Seigen Mori, Kousuke Ogata, and Michiya Hara \\ Department of Orthopaedic Surgery, \\ Fukuoka University School of Medicine
}

Eleven knees with bone grafts for tibial defects at the time of primary total knee arthroplasty were followed up for six to twenty-eight months. All patients achieved full weight bearing within two days after surgery. None of the patients developed apparent loosening of the tibial compornents or collapse of grafting bones. Bone grafting is a viable alternative to using custom tibial components or excess cement for tibial defects.

Key words : total knee arthroplasty (人工膝関節置換術), bone grafting (骨移植)

\section{はじめに}

はじめに変形性膝関節症 (以下 OA), 慢性関節リ ウマチ（以下 RA）の人工滕関節置換術（以下 TKA） に際したときに脛骨に骨欠損を有するものがあるが, 我々はこのような症例に対し可能な限り自家骨移植で 対応してきた．今回術後成績を検討したので報告する．

\section{対象および方法}

対象は 1995 年から 1997 年まで当科で PROFIX を 用いたTKAのうち，脛骨に骨欠損を有し，骨移植を 併用した OA 10 膝, RA 1 膝の計 11 膝である. 全 例が内反変形を呈していた。手術時年齢は 66 歳から 88 歳で平均 73.3 歳. 術後経過観察期間は 6 ケ月から 33 ケ月で平均 19.2 ケ月である.

手術は軟骨下骨をできるだけ温存する骨切りをし， 欠損部には骨切りによって得られた自家骨を適当な大 きさに加工し K-WIRE で仮固定後, 脛骨コンポーネ ントを設置し移植骨を安定させた（図 1)。なお 1 例 は骨欠損が大きく骨構築も悪かったためロングステム

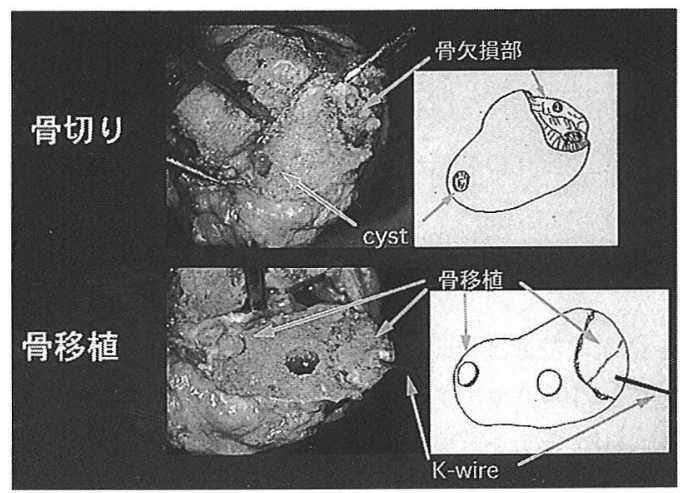

図 1 骨欠損部に自家骨をK-WIRE で仮固定後, 脛 骨コンポーネントを設置した.

を用いかつセメントを併用した，後療法は当科での一 般の TKA と同じく, 術後 1 ～ 2 日で全荷重を許可し た.

これらの症例に対し術前後の関節可動域（以下 ROM）を，またX 線写真で術前後の Femorotibial angle (以下 FTA), 術後の脛骨コンポーネントの設 


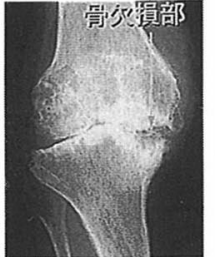

術前

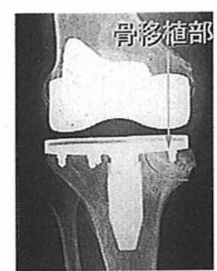

術直後

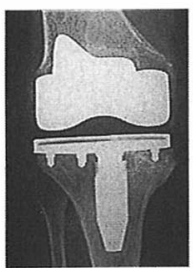

追跡時
図 2 症例 1，80歳，女性．RA. 内側脛骨関節面の $70 \%$ が陥凹していた，追跡時に脛骨コンポー ネントの設定角度に変化はない。

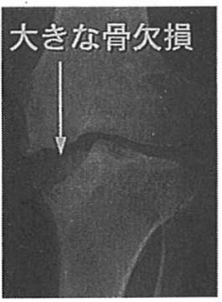

術前

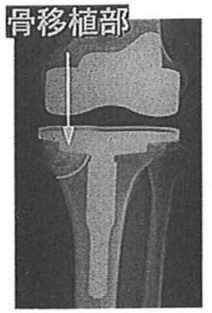

術直後

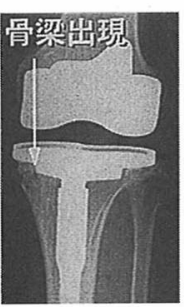

追跡時
図 3 症例 2, 73 歳，女性．破壊性関節症．内側脛骨 関節面は後方縁を残し全体的に $15 \mathrm{~mm}$ ほど陥 円していた，また脛骨母床も強度的に不安があっ たためロングステムを用いセメント併用した。 追跡時には骨移植部に骨梁を認める.

置角度の変化の有無および移植骨の推移について検討 した.

$$
\text { 結果 }
$$

関節可動域は術前平均－9.5～118.2 度から術後平均 -0.5〜100.0 度であった. X 線評価では，FTAは, 術前 187.5 度, 術後 174.2 度と安定した值となってい た、脛骨骨軸と脛骨コンポーネントの設置角度は, 正 面像での内側角が術後平均 89.4 度, 側面像での後傾 角が術後平均 86.3 度であり，両者ともに術後と追跡 時で有意差はなかった。移植骨は吸収を認めた症例は なく，ほとんどの症例で骨梁の連続が確認できた.

\section{症例}

症例 1, 80 歳, 女性. RA. 術前の FTA $190^{\circ}$, $R O M-30 \sim 120^{\circ}$ 。術中所見は脛骨内側顆関節面の $70 \%$ が陥凹していた。術後の FTA $173^{\circ}$ ， ROM
$-5 \sim 95^{\circ}$. 追跡時に脛骨コンポーネントの設定角度 に変化はない (図 2).

症例 2, 73 歳, 女性, 破壊性関節症。術前の FTA $193^{\circ}$ ，ROM 0 130 。術中所見は脛骨内側顆関節面 は後方縁を残し全体的に $15 \mathrm{~mm}$ ほど陥凹していた。 また脛骨母床も強度的に不安があったためロングステ ムを用い少量のセメントを併用した。術後の FTA $173^{\circ}$ ，ROM 0 110 。追跡時には骨移植部に骨梁を 認める（図 3).

\section{考察}

脛骨側の骨欠損に対して，骨移植，骨セメント，骨 欠損部を含めた大きな骨切りと厚いインサート，メ夕 ルウェッジ，段違いコンポーネントなどの方法が報告 されている。

この中で最小限の骨切りに骨移植を併用する方法は, 生理的な骨性支持を得ること，ボーンストック温存の 観点から一般に最良なものと考えられる。しかし問題 点としてコンポーネントの初期固定強度不足, 移植骨 の愈合不全, 吸収, 圧潰, 萎縮によるアライメントの 変化があげられ，これには骨欠損の大きさおよび母床 骨の状態が最も関連すると思われる。 Insall は $5 \sim 10 \mathrm{~mm}$ の深さの骨欠損が骨移植に適すると述べて いる2)。また脛骨骨切り部面積に占める骨移植部割合 の限界を, Dorr ら，守都らは $50 \%{ }^{1 / 3)}$ ，八野田らは $1 / 4^{5)}$ ，龍は $1 / 3$ と報告もそれぞれ異なり ${ }^{4)}$ ，一概に欠 損部の大きさだけでは判断出来ないと思われる。我々 は骨移植の適応限界について厳密に決めてはいない. しかし現在のところ 1 例を除き通常の脛骨コンポーネ ントに骨移植のみで骨欠損に対応し術後成績は良好で あったため，多くの症例に有効であると考える。しか し骨移植を優先させるあまりインプラントの初期固定 強度が低下し後療法の大幅な遅れや移植骨の圧潰など が危惧されるようでは本末転倒である。術前の X 線 による写真による骨欠損の大きさや骨萎縮の評価も重 要であるが, 術中のインプラント設置時の強度評価も 重要であると考える．初期固定強度が不足すると考え られる場合はロングステムの選択や，あるいは少量の セメントを併用するなどの工夫が必要であろう.

$$
\text { ま と め }
$$

(1)脛骨側の骨欠損に対し骨移植を併用したTKA 
11 膝の術後成績を検討した.

(2)全例において移植骨の吸収や脛骨インプラントの 設置角度に変化を認めず，術後成績は良好であった。

\section{参 考 文 献}

1) Dorr, L. D. et al.: Bone graft for tibial defects in total knee arthroplasty. Clin. Orthop., $205:$ 153-165, 1986.
2) Insall, J. N.: Surgical techniques and instrumentation in total knee arthroplasty. Surgery of the Knee, $26: 733-804$.

3）守都義明, 他：聓移植を併用した人亡膝関節置換術. 整形MOOK, $61: 165-173,1991$.

4）龍順之助：内反变形膝に対寸る人工関節于看術。関節外 科, $16: 38-46,1997$.

5）八野田実，他：人下膝関節置換術に打ける肖移植の成 績. 日関外誌, $7: 443-448,1988$. 